Technical Article

\title{
Origin and situation of some squares of railway stations
}

\author{
Iracema Clara Alves Luz ${ }^{1}$ and Patrícia Duarte de Oliveira Paiva ${ }^{1}$
}

\begin{abstract}
The squares originated in Brazil in the colonial period are frequently associated with administrative or religious. However, with the implementation of railways, this model underwent transformations and gardens began to be constructed in front of Railway Stations, as public squares. Nevertheless, the records of origins, histories, and factors involved in creating such spaces, as well as their evolution, are not enough known. Therefore, the objective was to understand their evolution by identifying the characteristics, highlighting the urban and landscape aspects that these gardens presented from their emergence until the present, using as a model four cases from cities in the state of Minas Gerais. The research was centered between the 19th century until nowadays, and the method applied was an interface between inventive and subjective analyses, associated with a bibliographical and iconographic survey, in addition to interviews. In all the analyzed situations, the gardens complemented, besides the station itself, buildings of eclectic architecture, where commercial, industrial activities and structures of support to the railroad operated. It was found that the gardens were built in these spaces mainly to provide a good aesthetic impression of the city for visitors that arrive through the railway. Although these gardens were references to the city where they were implanted, most of these spaces transformed over time, considering their uses and aspects, breaking the strong relationship between space and building.
\end{abstract}

Keywords: Landscaping, historic gardens, urban green areas, public spaces

\section{Resumo}

Origem e situação de praças de estação de trens

As praças originadas no período colonial no Brasil estão frequentemente associadas a edifícios estatais e religiosos. Mas, com a implantação das ferrovias, esse modelo passou por transformações e os jardins começaram a ser construídos em frente às Estações Ferroviárias, como praças públicas. No entanto, os registros de origens, histórias e os fatores envolvidos na criação desses espaços, bem como a sua evolução são pouco conhecidos. Dessa forma, objetivou-se identificar as características, destacando o aspecto urbanístico e paisagístico, que estes jardins apresentaram desde o seu surgimento até o presente, utilizando-se como modelo quatro casos cidades de cidades do estado de Minas Gerais. A pesquisa centrou-se entre o século XIX até os dias atuais, sendo o método aplicado uma interface entre as análises inventiva e subjetiva, associada ao levantamento bibliográfico, iconográfico e realização de entrevistas. Em todas as situações analisadas, os jardins complementavam, além da própria estação, prédios de arquitetura eclética, onde funcionavam atividades comerciais, industriais e estruturas de apoio à ferrovia. Constatou-se que os jardins foram construídos nesses espaços principalmente para proporcionar uma boa impressão estética da cidade para os visitantes que chegavam pelas Estações ferroviárias. Apesar de esses jardins terem sido referências para a cidade onde foram implantados, a maioria desses espaços passou por transformações ao longo do tempo, considerando seus usos e aspectos, rompendo a forte relação existente entre o espaço e prédio.

Palavras-chave: Paisagismo, jardins históricos, áreas verdes urbanas, espaços públicos.

\section{Introduction}

Squares are part of the daily life and memory of a city and can be considered historical, when are based on cultural, religious, political or social facts, of relevant importance for the society in which they are inserted. Also, these spaces may present architectural and symbolic value, which become landmarks for one society (Carta de Florença, 1999; Carta de Juiz de Fora, 2010).
In Brazil, several squares had their origin next to a religious building and served as space for festivities, performances, besides local commerce (Caldeira, 2010). And during their evolution, other functions as military, cultural or political also gave importance to these public spaces (Gomes, 2007).

Despite these peculiar relations, as observed as in many historical squares like Congonhas (Juste and Paiva, 2015), São João Del Rei (Mundim et al., 2017; Teixeira et al.,

${ }^{1}$ Universidade Federal de Lavras, Departemento de Agricultura, Lavras-MG, Brazil. *Corresponding author: iraaluz@hotmail.com

Received Nov 17, 2019 | Accepted Mar 02, 2020| Available online Mar 27, 2020

Licensed by CC BY 4.0

https://doi.org/10.1590/2447-536X.v26i1.2115

Area Editor: Márkilla Zunete Beckmann-Cavalcante 
2018), Mariana (Alves et al., 2016) and Ouro Preto (Alves et al., 2015), some had their origin in other important structure, such as railways and their Stations.

Besides of the railways in Brazil were incentivized to be constructed since 1835 by some laws that encourage their implementation, the majority was built only in the late 19th and early 20th century (Rodriguez, 2004). After that, in many Brazilian cities where railways were implemented, the front spaces of the Railway Stations were gardened, becoming spaces of great symbolic and historical value for the local community (Luz et al., 2017).

In this context, the objective was to analyze squares developed in areas next to railway stations in four cases in the state of Minas Gerais, by identifying their creation, landscaping aspects and, correlating the cases analyzed as well as their current status.

\section{Methodology}

For this study, four squares built in the 19th century from cities situated in the State of Minas Gerais were selected: Belo Horizonte (State capital), Divinópolis (Central region), Juiz de Fora (Midwest region), and Lavras (Southern region).

The exploratory research was centered on the morphological, social, historical, cultural, and landscaping aspects of the spaces, during the period of 1875 (Railway Station of Juiz de Fora opening date) to 2018.

Besides of field visits and documental, bibliographical, and iconographic research, some interviews were conducted to obtain information not recorded in documents about the squares, or elucidating them. Thus, historians and enthusiasts for the local or regional history were interviewed, as well as people who lived next to space at different times. The respondents were asked to answer the following key questions: What were the changes that you remember happening in this Square since its foundation?'; "What were the uses/functions that this square already had?"; "Did you use to attend this square?"; "Describe the reasons for using the space or not"; "How important is this Square to the city in which it is located and users of the place?"; "Is this square nice for use with leisure purposes?"; "Do you remember some remarkable fact that you lived or happened in this space?" and "What vegetation elements existed in this Square in other decades and that no longer exist today?".

The documental and iconographic research was carried out to obtain publications and records about the spaces and having been performed in municipal public libraries and public or private archives of the cities.

To analyze and understand the obtained data, the research was based on the theoretical contributions of Lassus (1994), Delphim (2005) and Luginbuhl (2006) which all together integrate the theoretical basis of this research. Through the inventive analysis (Lassus, 1994) is possible to identify the physical evolution processes and practices of the place, interpreting its natural, patrimonial and social data. This implies in discerning what would be most appropriate on the relationship between the place and its social practices. By the subjective analysis the aesthetic, phenomenological or symbolic values were identified (Luginbuhl, 2006). This method was based on the hypothesis that landscapes and their representations present values that were attributed by populations, artists, or writers that identified aesthetic or symbolic attributes in their works. Also, the singular aspects of the conception and evolution of one garden should be considered, since each space has its particularities (Delphim, 2005).

\section{Results and Discussion}

Railways and their stations appeared in Brazil from 1852 (Lima, 2009). Considering the studied cities, the Juiz de Fora railway was the first to be built in 1875 (Estações Ferroviárias do Brasil, 2018c), followed by that of Divinópolis, in 1890 (Estações Ferroviárias do Brasil, 2018b), Belo Horizonte (Estações Ferroviárias do Brasil, 2018a; MAO, 2018) and Lavras (Coimbra, 2009), both openning in 1895 .

\section{Railway Stations and their surroundings}

At the time of its construction, the railway was used for people and cargo transportation (Paula, 2008). And with its development, in the adjacencies of the Train Stations, the city had great growth, including houses, commerces, administrative buildings, warehouses, and industries (Galdino, 2015; Luz et al., 2017). Particularly for Belo Horizonte, the railway was built to transport materials and workers for building the new State capital (Calvo, 2013).

Regarding the Railway Station building, some were demolished and some still exist. The Belo Horizonte Central Station was built in 1894, designed by the architect José de Magalhães. In 1920 was demolished and a new one, designed by the Engineer Caetano Lopes, was opening in 1922 (IEPHA, 2018; MAO, 2018) (Figure 1a). Since 2002, the building holds the Museum of Arts and Crafts (MAO, 2018). The original station building of Divinópolis Station was demolished in 1916, and a new one was built in that same year (Estações Ferroviárias do Brasil, 2018b). In Juiz de Fora, the first station was built in 1877 and renovated in $1906^{1}$ (Figure 1b). The station building and the surrounds received some restorations and opening for visitation and events at specific periods.

In Lavras: the station building constructed in 1895, underwent three renovations until 1969 when it was demolished and gave place to a new one (Luz et al., 2017) (Figure 1b). Nowadays there is no use for the building and it is abandoned. 
(a)
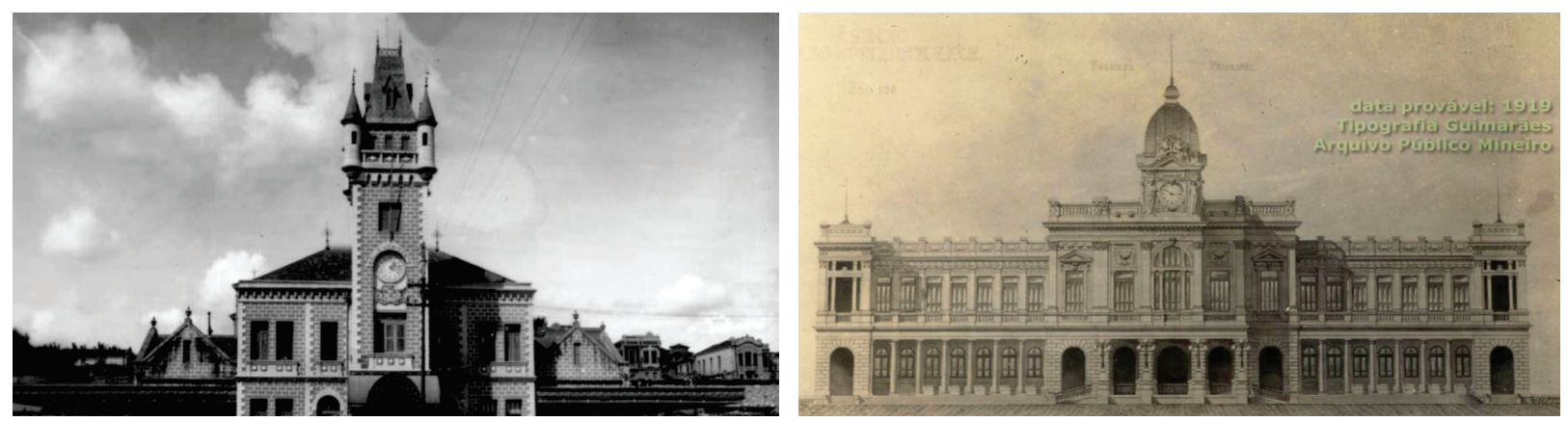

(b)
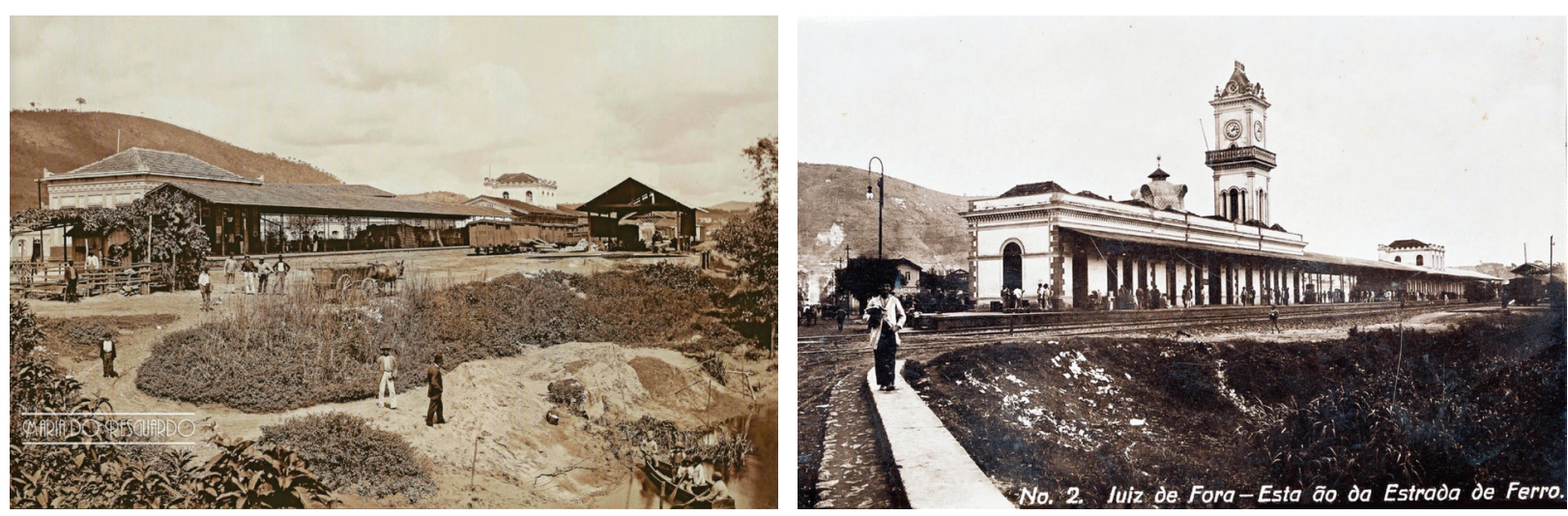

(c)


Figure 1. a) Belo Horizonte Railway Station. L: 1894. Photo: Unknown author; R: 1922. Photo: Unknown author. B) Juiz de Fora Railway Station. L: 1906. Photo: Unknown author; R: 1906. Photo: Unknown author C) Lavras Railway Station. L: Station Building - 1920s. Photo: Unknown author; R: New Station Building (in the background) - 1969.

Even with all the importance of these areas for the cities, over time, the Station Squares began to be degraded. One of the reasons was the creation of the new industrial poles in the 1940s (Bahia, 2005) and the industries located around the squares were gradually transferred to these new locations. Another reason was the valorization of road transportation from the 1970 s, with some news roads constructions (Silveira, 2002; Paula, 2008; Borges, 2011).

\section{The Squares of the railway stations}

Especially during the years 1870 and 1930 (Martins and Caixeta Filho, 1998; Borges, 2011) the number of people using the railway stations increased. The first impression offered to the travelers when arriving at the cities was the space surrounding the railway stations. This was recorded by Capistrano de Abreu, a writer and poet from Ceará that did a report regarding some of these spaces:

"Last week I met a retinue that was going to travel through a part of Minas Gerais served by E. F. Oeste de Minas that I had not yet visited (...). There were lunches, dinners, speeches, and the national anthem. We passed through Turvo, Lavras, Oliveira, Itapecerica, Divinópolis and Belo Horizonte. There were no vehicles, except in Lavras, where there is a line of trams and, from so many cities, I only appreciated what is visible from the station or the train."

(Rodrigues, 1977, Our undersocre) 
Considering the importance and value of these areas for the cities, gardens started to be designed, mainly by professionals from the railway companies, such as engineers, who did not have the specific knowledge in gardening (Luz et al., 2017).

The creation of the squares modified the view and use of the terrain, which turned into one of the beautiful spaces of the cities, being a place for leisure for the residents, besides hosting social and military movements.

\section{Landscape aspects of the Station Squares in their} beginnings

In most of the cities from this research, Station Square was, for a long time, an open space, without vegetation or with few plants. In Lavras, the gardening was planted only in the late 1940s (Luz et al., 2017), approximately 50 years after the station built. In Divinópolis, the square was built in $1937^{2}$, 47 years after the Station and for Juiz de Fora there was no information about the exact date.

The Station Square from Belo Horizonte began to be built in 1904, ending in 1906 (Jayme and Trevisan, 2012). In 1924, a renovation has been performed and the English design was substituted by classical French design, being constructed two water mirrors and some other structures. Also, some sculptures carved in white Carrara marble were installed, as the representative of the Four Seasons, tigers, lions, and nymphs (Werneck, 2012). The square presents a great amount of plants, most in free development, not in topiary, as it is common in classical gardens (Figure 2). Another important cultivated species are roses (Rosa spp.) that allowed a nice landscaping composition to the area (Werneck, 2012).

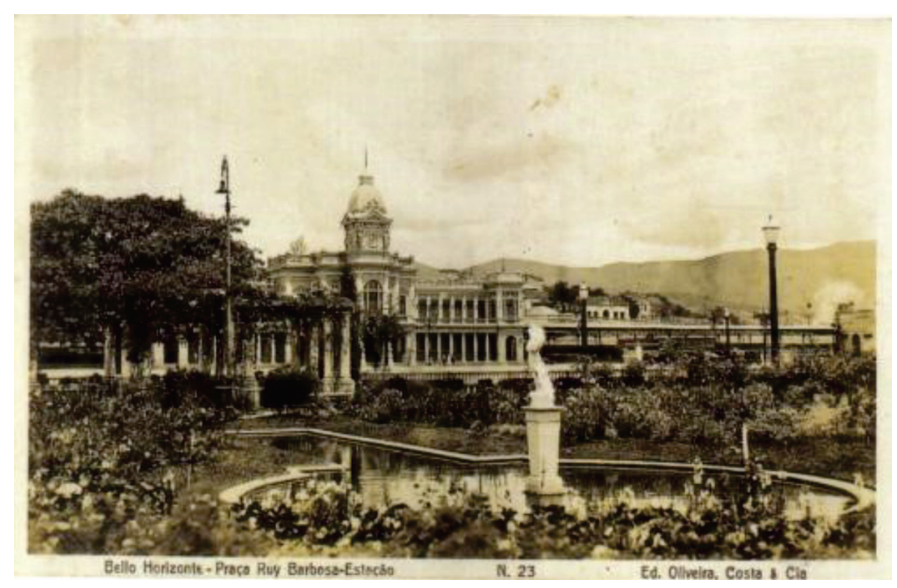

Figure 2. Belo Horizonte Station Square. Unknown date and author.

The Station Square of Divinópolis had similar structures in comparison to Belo Horizonte's square, presenting a water mirror and a bandstand (Figure 3). The difference was that in the Station Square of Belo Horizonte, these structures were installed due to a renovation, while in Divinópolis, during the construction period.

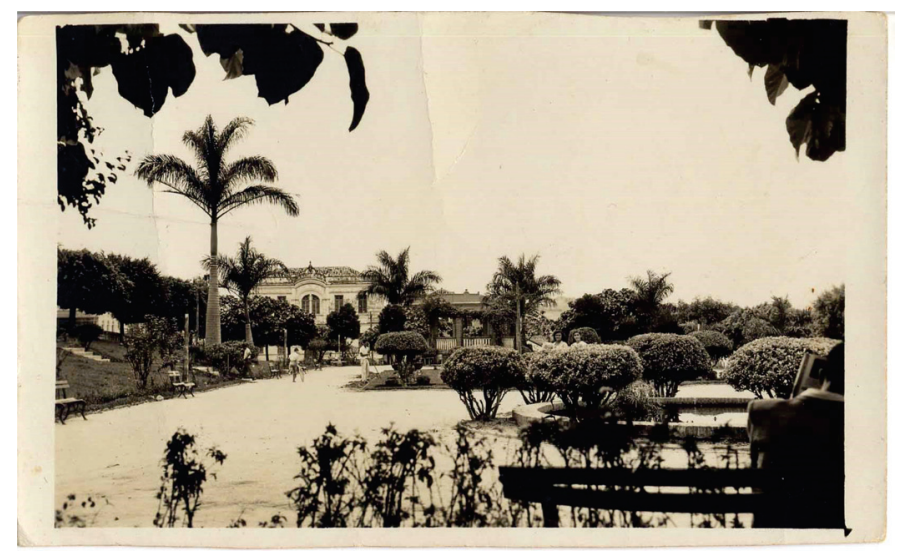

Figure 3. View of the water mirror and bandstand at Divinópolis Station Square. Unknown date and author. 
Some elements such as water mirrors, arbors and statues did not exist in the Station Squares of Juiz de Fora and Lavras. In Juiz de Fora, a bust was in a prominent position in the center of the square, surrounded by small beds raised with fodder and rose bushes (Rosa spp.). In Lavras, no significant structures were installed in the beginnings.

Therefore, there is a difference between landscaping treatments, distinguishing here two groups: squares from Belo Horizonte and Divinópolis, and another one, Lavras and Juiz de Fora.

In Belo Horizonte and Divinópolis, the squares had more regular forms, frequently square or rectangular, with larger dimensions reflecting in a well defined geometric trace. This allowed the insertion of some constructive elements, enabling these spaces being better elaborated. Lavras and Juiz de Fora had smaller areas squares, not allowing a good layout planning (Figure 4). In spite of this difference, all the gardens showed a classic (or inspiration on it) style.

Regarding the vegetation of these spaces, the composition should generally not be very dense. The trees were inserted on the sides, leading to the afforestation of the surrounding pathways of the square. Some small plants were used, including topiaries, besides rose bushes (Rosa spp.), jasmine (Jasminum spp.), figs (Ficus spp.), and conifers, giving a feeling of an organization for the space, concerning to the classic style. Also, some other species were cultivated, special in squares from Divinópolis and Lavras, like palm trees, biri-biri (Cana $X$ generalis) and cycas (Cyca revoluta), seems to be planted without any planning.

\section{Socio-cultural and historical aspects}

Becoming the "gateway to the city", the Station and its gardens became a setting for arrivals and departures of people in the late $19^{\text {th }}$ century and the first half of the $20^{\text {th }}$ century. This established a social relationship leaving deep marks in the memory of the communities (Paula, 2008). People transportation, for example, lead to a permanent contact between the company and its employees (railway workers), and the population that leaves close to the station (Paula, 2008). All of them used to use the square for leisure time.

In the beginnings, the square was one of the sites of the city most visited and photographed by tourists and residents. In Belo Horizonte, for example, the large circulation of people attracted photographers, who recorded them in the gardens for souvenirs, or for documents (Werneck, 2012).

With time, the squares started to receive some festivities and events. In Lavras, for carnival, groups composed by railway workers appropriated the space for celebration (Luz et al., 2017). In this area, some civic celebrations were performed as the reception for authorities and military (Há 80 anos..., 2014).
In Divinopolis, soldiers assembled before a trip to integrate World War $\mathrm{II}^{3}$ or in commemoration of the city day $^{4}$. In any case, this record shows how the square was an important point of social interaction.

\section{The denominations of the Squares and their relation} with the railway

Regarding the denomination that these squares there are the influence of personalities linked to the cause of its origin. In Belo Horizonte, originally was named Praça da Estação started, from 1914 to 1923 , to be named Praça Cristiano Otoni, in honor of the influential Mineiro politician of the railway sector (MAO, 2018). In Divinópolis, the square was initially named as Pedro Xavier Gontijo, as a tribute to the supporter of this transport in the municipality ${ }^{5}$. In Lavras, the square was, since its inauguration, named Dr. José Esteves, as a reference to the doctor who provided free medical services to the community and who used to live in the adjacencies of this space (Luz et al., 2017). The only exception is Juiz de Fora that throughout its existence had only one denomination, Dr. João Penido, a tribute to an important city doctor (CPDOC, 2018).

Despite the honors conferred on these important personalities and the change of nomenclature that has taken place throughout their history, all these squares continuous to be called "Station Squares".

\section{Historical heritage}

In Belo Horizonte, the architectural and landscaping complex of the Station Square, as well as the Central Station, the former railway station Oeste de Minas and other surrounding buildings, was listed by IEPHA/MG State Institute of Historic and Artistic Heritage of Minas Gerais - in 1988 (MAO, 2018).

In Divinópolis, only to the railway building was also listed in 1988 (Estações Ferroviárias do Brasil, 2018b), since, in 1962, the Station Square completely disappeared, given place to a bus terminal (Divinópolis, 2018).

In 2006 the work sheds of the railroad and in 2016, the square from Lavras station area were listed in the municipal scope (Lavras, 2017). Since the square was not included, many modifications were performed, some without a landscaping plan. The layout is maintained, but plants composition is completely uncharacterized. Also, some structures were introduced as a taxi stand and police point. In Juiz de Fora, besides of the square and the Railway Station, the historical buildings surrounding the area were all listed (Juiz de Fora, 2002; FUNALFA, 2018; Juiz de Fora, 2019), but not the square, allowing many modifications along the time. The protection of these spaces allowed more drastic and even irreversible interventions to occur, like happened in Divinópolis.

The discrepancy of protection afforded to the architectural set is reflected in the way how the gardens were

${ }^{3}$ FLORA, F. (Divinópolis - MG). Personal communication, 2018.

${ }^{4}$ SILVA, W. S. T. (Divinópolis - MG). Personal communication, 2016.

${ }^{5}$ FLORA, F. op. cit. 


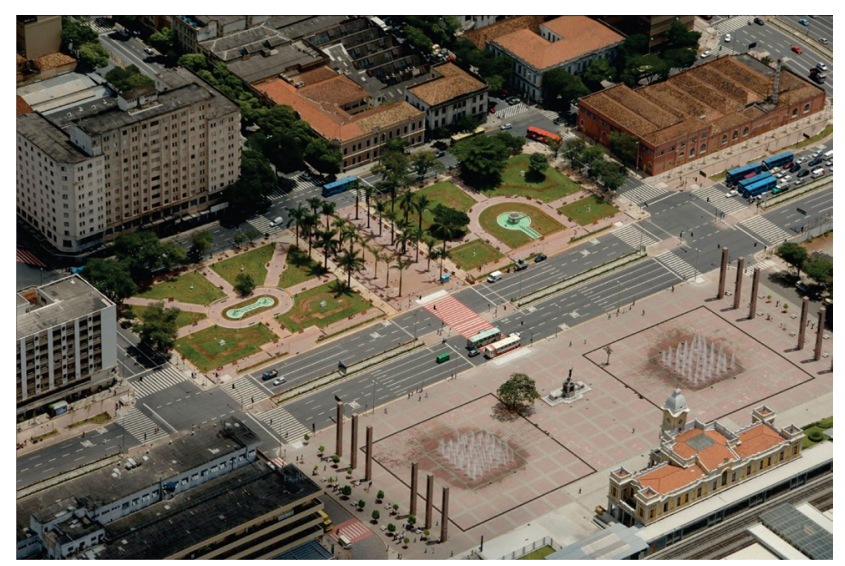

(a)
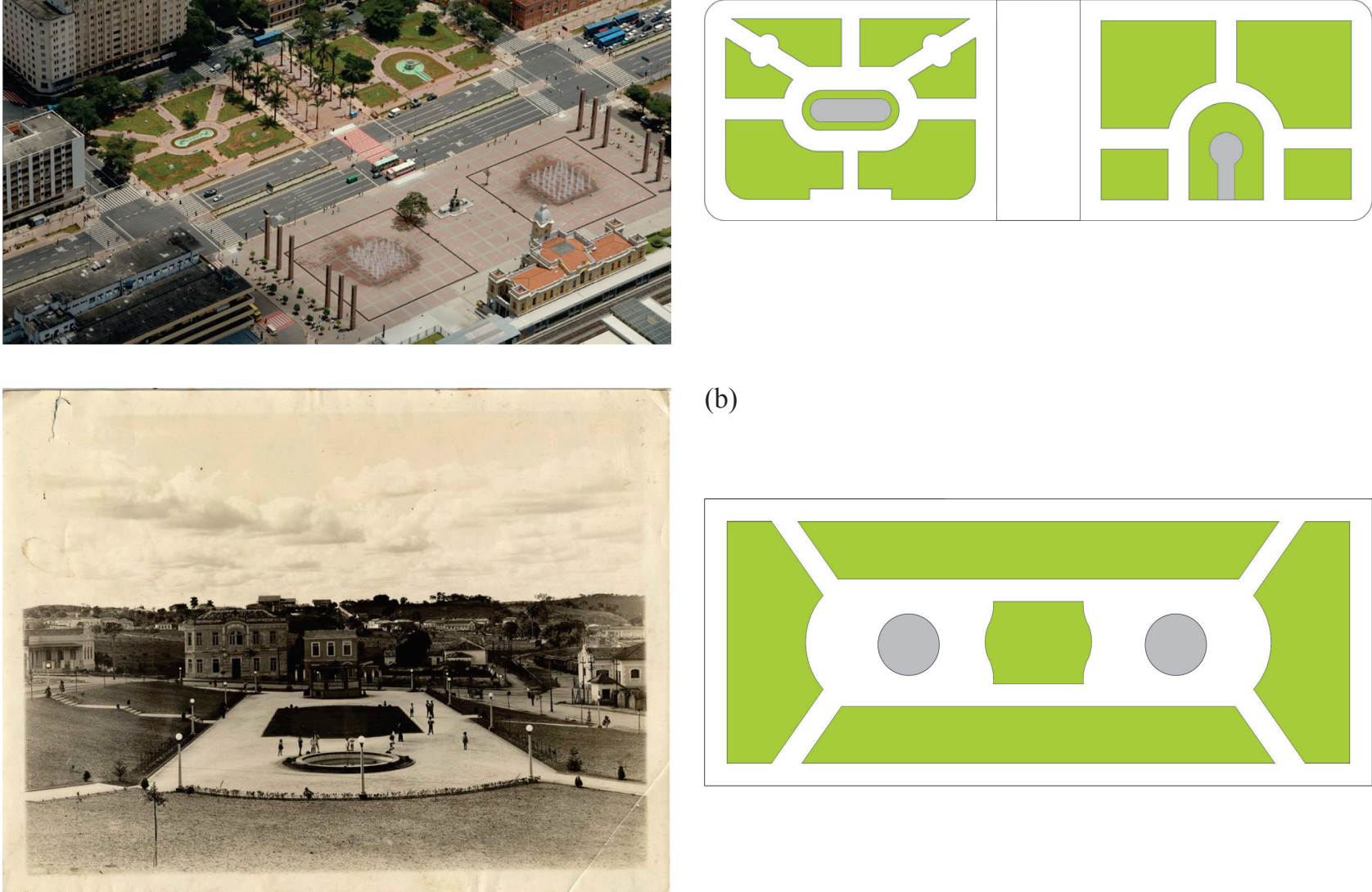

(b)

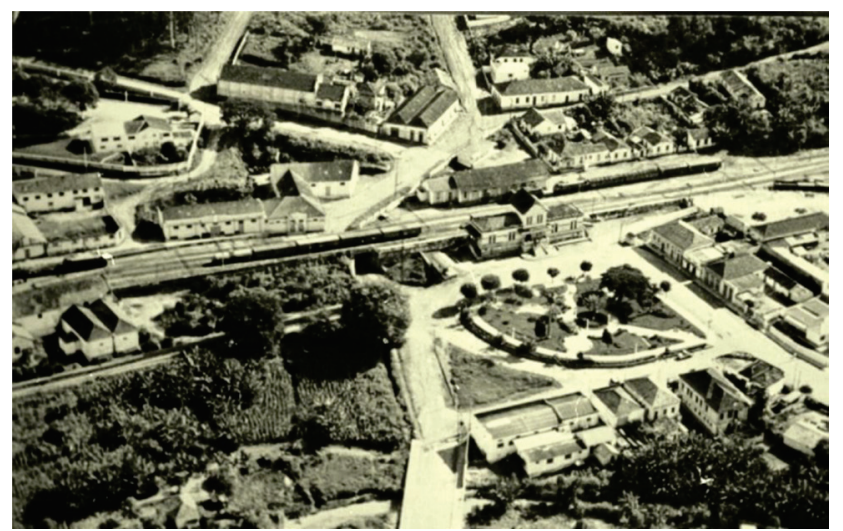

(c)
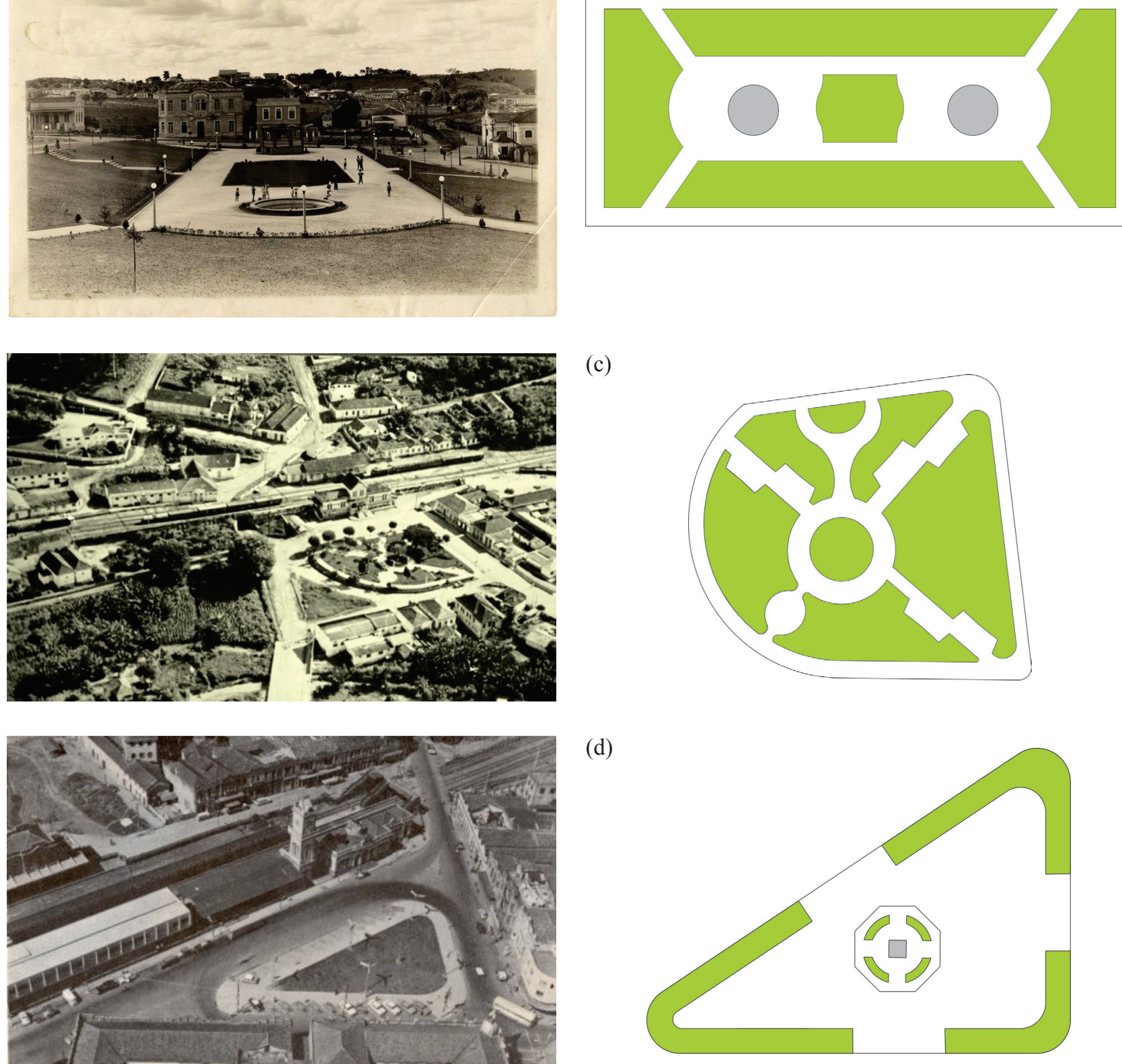

(d)

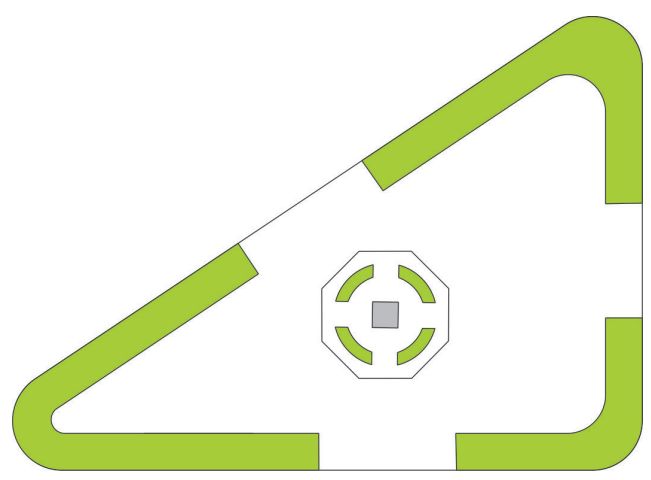

Figure 4. The design of the Station Squares. a) Belo Horizonte. b) Divinópolis, in the 1930s.

c) Lavras, in the 1960s. d) Juiz de Fora, in 1969. 
cared for. In Belo Horizonte, the place was uncharacterized due to various interventions, such as in 1963 when for the construction of the Andradas Av., two modules of the square gardens were reduced and some sculptures were withdrawal (Werneck, 2012). But in 2004, after a renovation, the fountains were reinstalled, the gardens restored, keeping the original layout, and the original sculptures from the 1920s were also replaced (Werneck, 2012).

\section{Gardening and current uses of the Station Squares}

In spite of the different forms of treatment given to Station Squares, it is possible to notice that the layout of these spaces remains preserved in some of them. But in Juiz de Fora, the layout was completely modified and in Divinópolis, the square was suppressed.

Concerning to the vegetation, in all of them, modifications were performed. These squares are currently walking area and not destinated to purposes as leisure, mainly due to the habits modification of the residents. Besides of this, on some occasions, the areas received some cultural ou political events, attracting many people.

In Lavras, however, due to the mischaracterization of the Station Square and the Station building, the area is not attractive for any use, like leisure or for events.

In general, what was possible to perceive is that with the deactivation of the railways, over time, the squares and the surrounded areas lost their glamour, beauty, and attractiveness. What we have today is a great historical value, mainly connected to the preserved buildings.

\section{Conclusions}

The purpose of gardens creation next to the railway stations was to give aesthetical value to space, making them in past important areas in the cities. The gardens were in the classical model, following the trends of the time of their creation.

Over time, the spaces lost their importance, since the railways also were not as important as in the past. Some areas disappeared and others were modified, mischaracterizing their original layout. An exception is for Belo Horizonte, since it is the capital and the area is protected, retaining the characteristics of its beginnings.

\section{Authors contribution}

I.C.A.L. ${ }^{0000-0002-7459-7212}$ : developed the idea, performed the research and interviews, analyzed the data, took the photos, and

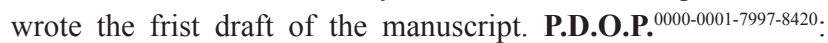
helped in developing the idea of the research and in adapting the methodology, as well as critical reading and editing of the manuscript.

\section{Acknowledgements}

The authors are thankful to Fapemig, Capes and CNPQ for the financial support and scholarships.

\section{References}

ALVES, S.F.N.S.C.; GARCIA, C.S.G.; PAIVA, P.D.O. Transformações físicas e apropriações sociais da Praça Tiradentes em Ouro Preto-MG. Ornamental Horticulture, v.21, n.2, p.209-220, 2015. DOI: http:// dx.doi.org/10.14295/aohl.v21i2.670

ALVES, S.F.N.S.C.; PAIVA, P.D.O.; GARCIA, C.S.G. Largo do Rossio to a garden: the genesis of the Gomes Freire's square in Mariana-MG. Ornamental Horticulture, v.22, n.3, p.350-360, 2016. DOI: https://doi.org/10.14295/oh.v22i3.955

BAHIA, C.L.M. Belo Horizonte: uma cidade para a modernidade mineira. Cadernos de Arquitetura e Urbanismo, v.12, n.13, p.185-200, 2005.

BORGES, B.G. Ferrovia e modernidade. Revista UFG, n.11, p.27-36, 2011.

CALDEIRA, J.M. A praça colonial brasileira. Revista Universitas: Arquitetura e Comunicação Social, v.7, n.1, p.19-39, 2010. DOI: http://dx.doi.org/10.5102/uc.v7i1.1113

CALVO, J. Belo Horizonte das primeiras décadas do século XX: entre a cidade da imaginação à cidade das múltiplas realidades. Cadernos de História, v.14, n.21, 71-93, 2013. DOI: 10.5752/P.2237-8871.2013v14n21p71

CARTA DE FLORENÇA: Carta dos jardins históricos. Icomos, 1981. In: Cadernos de Sociomuseologia, Lisboa, n. 15, p. 201-208, 1999.

CARTA DE JUIZ DE FORA: Carta dos jardins históricos brasileiros. Juiz de Fora: IPHAN, 2010. 13p.

CPDOC - CENTRO DE PESQUISAE DOCUMENTAÇÃO DE HISTÓRIA CONTEMPORÂNEA DO BRASIL. Penido, João Nogueira. Available at: <http://www.fgv.br/ cpdoc/acervo/dicionarios/verbete-biografico/penido-joaonogueira $>$. Accessed on: September $23^{\text {rd }} 2018$.

COIMBRA, R.R. Uma viagem pelos trilhos da CentroOeste: 120 anos de história ferroviária. São Lourenço: Novo Mundo, 2009. 134p.

DELPHIM, C.F.M. Intervenção em jardins históricos: manual. Brasília: IPHAN, 2005. 152p.

DIVINÓPOLIS. Prefeitura Municipal. História. Available at: <https://www.divinopolis.mg.gov.br/portal/cidade/13/ Hist\%C3\%B3ria>. Acessed on: July 13, 2018.

ESTAÇÕES FERROVIÁRIAS DO BRASIL. Belo Horizonte (antiga Minas). Available at: $<$ http://www. estacoesferroviarias.com.br/efcb_mg_paraopeba/ belohorizonte.htm>. Accessed on: May 28, $2018 \mathrm{a}$. 
ESTAÇÕES FERROVIÁRIAS DO BRASIL. Divinópolis (antiga Henrique Galvão). Available at $<\mathrm{http}: / / \mathrm{www}$. estacoesferroviarias.com.br/rmv garcas/divinopolis.htm>. Acessed on: May 28, 2018b.

ESTAÇÕES FERROVIÁRIAS DO BRASIL. Juiz de Fora. Available at: $<$ http://www.estacoesferroviarias.com. br/efcb_mg_linhacentro/juizfora.htm>. Acessed on: May $28,2018 \mathrm{c}$.

FUNALFA - FUNDAÇÃO CULTURAL ALFREDO FERREIRA LAGE. Bens imóveis tombados. Available at: <https://www.pjf.mg.gov.br/administracao_indireta/ funalfa/patrimonio/lista_imoveis.php $>$. Accessed on: July 12,2018 .

GALDINO, C. Breve análise sobre a influência da indústria ferroviária brasileira em ambientes rurais e urbanos. Cadernos do CEOM, v.28, n.42, p.35-43, 2015.

GOMES, M.A.S. De largo a jardim: praças públicas no Brasil: algumas aproximações. Estudos Geográficos, v.5, n.1, p.101-120, 2007.

HÁ 80 ANOS chegavam a Lavras, os homens do $8^{\circ}$ BCM. Jornal de Lavras, Lavras, 20 mar. 2014. Available at: $<\mathrm{http}: / / \mathrm{www}$.jornalde lavras.com.br/ index. $\mathrm{php} ? \mathrm{p}=10 \& \mathrm{tc}=4 \& \mathrm{c}=8185>$. Accessed on: July 18, 2018.

IEPHA - INSTITUTO ESTADUAL DO PATRIMÔNIO HISTÓRICO E ARTÍSTICO DE MINAS GERAIS -. Conjunto paisagístico e arquitetônico da Praça Rui Barbosa (Praça da Estação). Available at: <http://www. iepha.mg.gov.br/index.php/programas-e-acoes/patrimoniocultural-protegido/bens-tombados. Accessed on: July 25, 2018.

JAYME, J.G.; TREVISAN, E. Intervenções urbanas, usos de ocupações de espaços na região central de Belo Horizonte. Civitas, v.2, p.359-377, 2012.

JUIZ DE FORA. DECRETO N. ${ }^{\circ} 7327$, de 04 de abril de 2002. Dispõe sobre a criação do Conjunto Paisagístico que menciona. Available at: <https://jflegis.pjf.mg.gov. br/c_norma.php?chave $=0000020045>$. Accessed on: February 17, 2019.

JUSTE, L.C.; PAIVA, P.D.O. Historic rescue of the square of the Basílica of Bom Jesus de Matosinhos at Congonhas, Minas Gerais. Ornamental Horticulture, v.21, n.1, p.6376, 2015. DOI: 10.14295/rbho.v21i1.777

LASSUS, B. L'obligation de I'inventio: du paysage aux ambiances successives. In: BERQUE (Dir.). Cinq propositions pour unethéorie du paysage. Paris: Champ Vallon, 1994, p.81-106.
LAVRAS. Prefeitura Municipal. Patrimônio - bens tombados. Lavras, 23 nov. 2017. Available at: $<\mathrm{http}: / / \mathrm{pml}$. lavras.mg.gov.br/conteudo/texto/1765>. Accessed on: July 23, 2018.

LIMA, P.L.O. Ferrovia, sociedade e cultura, 1850-1930. Belo Horizonte: Argvmentvm, 2009. 160p.

LUGINBUHL, Y. Paysage et identification, qualification et objectifs de qualités. Paysage et développement durable: les enjeux de la convention européenne du paysage. Strasbourg: I'Europe, 2006, p.107-125.

LUZ, I.C.A.; PAIVA, P.D.O; ALVES, S.F.N.S.C. Train station area gardens: the creation and evolution of Dr. José Esteves Square, in Lavras-MG. Ornamental Horticulture, v.23, p.432-443, 2017. DOI: http://dx.doi.org/10.14295/ oh.v23i4.1117

MAO - MUSEU DE ARTES E OFICIOS. O Edifício e a Praça. Available at: <http://www.mao.org.br/conheca/oedificio-e-a-praca/>. Accessed on: May 28, 2018.

MARTINS, R.S.; CAIXETA FILHO, J.V. O desenvolvimento dos sistemas de transporte: auge, abandono e reativação recente das ferrovias. Teoria e Evidência Econômica, v.6, n.11, p.69-91, 1998.

MUNDIM, A.S.; PAIVA, P.D.O.; SOUZA, R.B.; BONIFÁCIO, F.L.; ALVES, S.F.N.S.C. Origin, historical and landscape evolution of the Expedicionários Square, São João Del Rei-MG. Ornamental Horticulture, v.23, n.4, p.460-467, 2017. DOI: http://dx.doi.org/10.14295/ oh.v23i4.1118

PAULA, D.A. 154 anos de ferrovia no Brasil: para onde caminha esse trem? História Revista, v.13, n.1, p.45-69, 2008.

RODRIGUEZ, H.S. A formação das estradas de ferro do Rio de Janeiro: o resgate da sua memória. Rio de Janeiro: Memória do Trem. 2004. 192p.

SILVEIRA, M.R. Transporte e logística: as ferrovias no Brasil. Revista Geosul, v.17, n.34, p.63-86, 2002.

TEIXEIRA, A.B.; ANDRADE, N.C.; ALVES, S. F. N. S. C. Historical rescue of Dr. Salatiel square: the garden of the Cachaça's Largo São João del-Rei, Minas Gerais State, Brazil. Ornamental Horticulture, v.24, n.1, p.34-43. DOI: doi.org/10.14295/oh.v24il.939

WERNECK, G. Conheça as estátuas nômades das quatro estações em BH. Jornal Estado de Minas, Belo Horizonte, 17 mar. 2012. Available at: < https://www.em.com.br/app/ noticia/gerais/2012/03/17/interna_gerais,283964/conhecaas-estatuas-nomades-das-quatro-estacoes-em-bh.shtml $>$. Accessed on: February 16,2019. 